\title{
Komposisi Media Pertumbuhan Protokorm Sebelum Perlakuan Kolkisin untuk Meningkatkan Poliploidi pada Phalaenopsis amabilis (L.) Blume
}

\section{Protocorm Growth Medium Composition Before Colchicine Treatment to Increase Polyploidy on Phalaenopsis amabilis (L.) Blume}

\author{
Astrid Aditya Putri', Dewi Sukmaª ${ }^{2 *}$, Sandra Arifin Aziz $^{2}$, dan Muhamad Syukur ${ }^{2}$ \\ 'Program Studi Pemuliaan dan Bioteknologi Tanaman, Sekolah Pascasarjana, Institut Pertanian Bogor \\ ${ }^{2}$ Departemen Agronomi dan Hortikultura, Fakultas Pertanian, Institut Pertanian Bogor \\ (Bogor Agricultural University), Jl. Meranti, Kampus IPB Darmaga, Bogor 16680, Indonesia
}

Diterima 10 Mei 2017/Disetujui 23 Agustus 2018

\begin{abstract}
Polyploidy induction in Phalaenopsis amabilis is one of the methods to increase genetic diversity. A highly meristematic condition of protocorm induced by cytokinines may improve the success rate of polyploidy induction. This experiment was aimed to study the effect of Benzylaminopurine (BAP), Thidiazuron (TDZ) and coconut water (CW) in a half concentration of Murashige \& Skoog (MS) medium before colchicine treatment on growth, multiplication and the success rate of polyploidy induction on Phalaenopsis amabilis protocorm. The experiment used completely randomized design with one factor, medium treatment (15\% of CW); $0.51 \mathrm{mg} \mathrm{L}^{-1} \mathrm{BAP} ; 0.50 \mathrm{mg} \mathrm{L} \mathrm{L}^{-1} \mathrm{TDZ} ; 15 \% \mathrm{CW}+0.51 \mathrm{mg} \mathrm{L}^{-1} \mathrm{BAP} ; 15 \% \mathrm{CW}+0.50 \mathrm{mg} \mathrm{L} \mathrm{L}^{-1} \mathrm{TDZ}$ ). Each treatment consisted of three replications with five culture bottles of protocorm for each replication and ten protocorms per bottle. The protocorms were incubated for eight weeks in the medium before treated with $50 \mathrm{mg} \mathrm{L}^{-1}$ of colchicine for ten days. The results showed that $15 \% \mathrm{CW}, 15 \% \mathrm{CW}+0.51 \mathrm{mg} \mathrm{L}^{-1} \mathrm{BAP}$ or $0.5 \mathrm{mg} \mathrm{L^{-1 }} \mathrm{TDZ}$ gave the highest percentage (100\%) of alive protocorm. The highest percentages of protocorm multiplication were resulted from $15 \% \mathrm{CW}+0.51 \mathrm{mg} \mathrm{L}^{-1} B A P(65.3 \%)$ and $15 \% \mathrm{CW}+0.5 \mathrm{mg} \mathrm{L^{-1 }} \mathrm{TDZ}(62.7 \%)$. The best treatment to promote formation of leaves and roots from protocorm was $15 \%$ $\mathrm{CW}$. The percentage of polyploid plantlets of $3 \%$ was found in plantlet from $15 \% \mathrm{CW}+0.50 \mathrm{mg} \mathrm{L}-1 \mathrm{TDZ}$ media treatment while from other treatments could not be detected.
\end{abstract}

Keywords: BAP, chromosome, coconut water, plantlet, TDZ

\section{ABSTRAK}

Induksi poliploidi pada Phalaenopsis amabilis merupakan salah satu metode dalam peningkatan keragaman genetik tanaman. Kondisi meristematik pada protokorm yang dapat diinduksi sitokinin diduga dapat meningkatkan keberhasilan induksi poliploidi. Penelitian ini bertujuan untuk mempelajari pengaruh BAP, TDZ dan air kelapa dalam setengah konsentrasi media Murashige \& Skoog (1/2MS) sebelum perlakuan kolkisin terhadap pertumbuhan, multiplikasi, dan keberhasilan induksi poliploidi pada protokorm Phalaenopsis amabilis. Percobaan menggunakan rancangan acak lengkap dengan satu faktor, yaitu perlakuan media media terdiri dari 5 perlakuan (15\% air kelapa (AK); 0,51 mg L L BAP; 0,5 mg L L TDZ; 15 $\% A K+0,51 \mathrm{mg} L^{-1} B A P ; 15 \% A K+0,5 m g L^{-1} T D Z$ ). Setiap perlakuan diulang sebanyak 3 kali, setiap ulangan terdiri dari 3 botol yang masing-masing berisi 10 protokorm. Protokorm diinkubasi dalam media perlakuan selama 8 minggu, lalu diberi perlakuan perendaman dalam kolkisin $50 \mathrm{mg} \mathrm{L}^{-1}$ selama 10 hari. Hasil penelitian menunjukkan persentase protokorm hidup tertinggi (100\%) dihasilkan pada perlakuan $15 \% \mathrm{AK}, 15 \% \mathrm{AK}+0.51 \mathrm{mg} \mathrm{L}^{-1} \mathrm{BAP}$, dan $15 \% \mathrm{AK}+0.50 \mathrm{mg} \mathrm{L^{-1 }} \mathrm{TDZ}$. Persentase protokorm bermultiplikasi tertinggi dihasilkan dari perlakuan $15 \%$ AK $+0.51 \mathrm{mg} \mathrm{L}^{-1}$ BAP (65.3\%) dan $15 \%$ AK $+0.51 \mathrm{mg} \mathrm{L} \mathrm{L}^{-1} \mathrm{TDZ}(62.7 \%)$. Morfogenesis protokorm membentuk daun dan akar paling baik terdapat pada perlakuan $15 \%$ AK. Persentase planlet poliploid sebesar 3\% ditemukan pada plantlet dari perlakuan media $15 \% \mathrm{AK}+0.50 \mathrm{mg} \mathrm{L} \mathrm{L}^{-1} \mathrm{TDZ}$ sedangkan pada planlet dari perlakuan lainnya tidak dapat dideteksi.

Kata kunci: air kelapa, BAP, kromosom, planlet, TDZ

\footnotetext{
* Penulis untuk korespondensi. e-mail: dsukma70@gmail.com
} 


\section{PENDAHULUAN}

Phalaenopsis amabilis Blume sangat potensial untuk dikembangkan sebagai tetua persilangan dan memiliki nilai ekonomi yang tinggi sebagai spesies yang membawa warna putih bersih. Menurut Chen et al. (2011), pengembangan varietas baru anggrek Phalaenopsis dengan karakter unggul secara terus menerus diperlukan karena menjadi penentu keberlanjutan industri anggrek. Spesies-spesies Phalaenopsis memiliki jumlah kromosom dasar $2 \mathrm{n}=2 \mathrm{x}=38$ (diploid) sedangkan varietas-varietas hibrida komersial yang populer biasanya poliploid. Beberapa contoh Phalaenopsis poliploid adalah Phal. Sunrise Goldmour 'KHM637' (tetraploid) dan Phal. Taipei Gold 'STM' (triplod) (Chuang et al., 2008; Chuang et al., 2013).

Poliploidi merupakan peristiwa yang umum dalam tanaman yang melibatkan akuisisi lebih dari dua set lengkap kromosom (Del Pozo dan Ramirez-Parra, 2015). Tanaman poliploid biasanya menunjukkan vigor yang lebih baik dibanding diploidnya, mengatasi efek kerusakan karena mutasi, meningkatkan heterozigositas, dan heterosis (Sattler et al., 2016). Usaha dalam memperoleh anggrek poliploid telah banyak dilakukan, diantaranya oleh Khosravi et al. (2009) pada anggrek Dendrobium 'Serdang Beauty', Kerdsuwan dan Te-chato (2012) pada anggrek Rhynchostilis gigantea var. Rubrum Sagarik, Sarathum et al. (2010) pada anggrek Dendrobium scabrilingue, Atichart (2013) pada Dendrobium chrysotoxum, Rahayu et al. (2015) pada Phal. amabilis dan Phal. amboinensis, dan Azmi et al. (2016) pada Phal. amabilis.

Penelitian induksi poliploid sering mengalami kesulitan terkait metode yang efektif untuk menghasilkan individu poliploid dengan persentase tinggi. Jenis bahan tanaman akan menentukan sel apa yang menjadi target duplikasi kromosom, salah satunya adalah protokorm (Azmi et al., 2016). Protokorm merupakan istilah untuk struktur globular sebagai bentuk lanjut dari hasil perkecambahan embrio anggrek. Protokorm primer dari perkecambahan embrio dapat membentuk protokorm sekunder atau sering disebut sebagai protocorm-like bodies (PLBs). Pada anggrek, induksi poliploid menggunakan kolkisin pada eksplan protokorm dilakukan untuk menargetkan duplikasi kromosom pada sel somatik yang bersifat meristematik (Arditti, 2008). Protokorm pada fase pembelahan sel aktif sangat potensial untuk bahan induksi poliploidi, namun karena protokorm sudah berada pada fase multiseluler, maka ploidisasi kemungkinan hanya terjadi pada satu atau beberapa inti sel saja. Selanjutnya kemungkinan terjadi diplontic selection, yaitu perubahan pada protokorm yang mengarah pada recovery menjadi kondisi diploid kembali ataupun campuran sel-sel diploid dan poliploid atau yang sering disebut mixoploid. PLBs mixoploid ketika membentuk planlet akan menjadi tanaman kimera dimana hanya beberapa sel atau organ tertentu saja yang bersifat poliploid.

Perbaikan metode induksi poliploid pada protokorm Phal. amabilis masih perlu dilakukan untuk meningkatkan persentase tanaman poliploid. Salah satu metode alternatif adalah menggunakan media pra-perlakuan dengan penambahan hormon sitokinin sintetis ataupun bahan organik mengandung hormon yang diduga dapat mendorong kondisi meristematik tinggi pada sel-sel PLBs. Pada kultur jaringan hormon sitokinin memiliki dua peran penting, yaitu dapat merangsang morfogenesis eksplan dan merangsang pembentukan tunas muda (Hopkins, 1999). Penggunaan hormon sitokinin untuk meningkatkan regenerasi dan multiplikasi pada protokorm tanaman anggrek telah dilakukan oleh Chen dan Chang (2004), Chugh et al. (2009), Nuraini et al. (2010), Nikjenad et al. (2011), serta Raynalta (2013). Penelitian ini bertujuan untuk mempelajari pengaruh BAP, TDZ dan air kelapa dalam setengah konsentrasi media Murashige \& Skoog (1/2MS) sebelum perlakuan kolkisin terhadap pertumbuhan, multiplikasi dan keberhasilan induksi poliploidi pada protokorm Phal. amabilis.

\section{BAHAN DAN METODE}

Penelitian ini dilaksanakan mulai bulan Oktober 2015 sampai dengan Oktober 2016. Penelitian ini dilaksanakan di Laboratorium Kultur Jaringan Tanaman 1 dan Laboratorium Mikroteknik, Departemen Agronomi dan Hortikultura, Institut Pertanian Bogor.

\section{Uji Pertumbuhan Protokorm}

Rancangan percobaan yang digunakan pada percobaan ini adalah Rancangan Acak Lengkap (RAL) dengan perlakuan komposisi media PLBs sebelum perlakuan kolkisin. PLBs dihasilkan dari hasil multiplikasi protokorm dari perkecambahan benih Phalaenopsis amabilis, berumur sekitar 6 bulan setelah perkecambahan. Media dasar yang digunakan adalah setengah konsentrasi media dasar Murashige Skoog (1/2MS). Perlakuan terdiri atas media $1 / 2 \mathrm{MS}$ dengan penambahan: a) $15 \%$ air kelapa (AK); b) $0.51 \mathrm{mg} \mathrm{L}^{-1} \mathrm{BAP}$; c) $0.50 \mathrm{mg} \mathrm{L}^{-1} \mathrm{TDZ}$; d) $15 \% \mathrm{AK}+0.51$ $\mathrm{mg} \mathrm{L}^{-1}$ BAP; dan e) $15 \% \mathrm{AK}+0.50 \mathrm{mg} \mathrm{L}^{-1} \mathrm{TDZ}$. Setiap perlakuan diulang sebanyak 3 kali, dan setiap ulangan terdiri atas 3 botol, setiap botol ditanami 10 PLBs, sehingga total PLBs yang digunakan dalam percobaan adalah 450 PLBs. Pengkulturan di media perlakuan dilakukan hingga 8 minggu setelah subkultur (MSS) lalu diamati persentase PLBs hidup, bermultiplikasi, berdaun, dan berakar. Pengolahan data menggunakan dianalisis sidik ragam, jika perlakuan berpengaruh nyata, diuji lanjut dengan uji Tukey pada $\alpha$ sebesar $5 \%$.

\section{Induksi Poliploidi dengan Kolkisin}

PLBs yang diuji pertumbuhan pada berbagai komposisi media perlakuan seperti dijelaskan pada bagian Uji Pertumbuhan Protokorm di atas; setelah 8 minggu pengkulturan diberi perlakuan kolkisin dengan cara direndam dalam larutan kolkisin $50 \mathrm{mg} \mathrm{L}^{-1}$ (konsentrasi optimum yang diperoleh Azmi et al., 2015). Rendaman PLBs dalam kolkisin ditempatkan pada shaker dengan kecepatan rotasi $120 \mathrm{rpm}$ selama 10 hari. Setelah perendaman, PLBs dikeluarkan dari 
larutan kolkisin, dibilas 3 kali dengan aquades steril lalu dikulturkan dalam media pemulihan yaitu media 1/2MS yang ditambahkan air kelapa 7.5\% (v/v), diinkubasi dalam ruang kultur bersuhu $23-25{ }^{\circ} \mathrm{C}$ dengan cahaya lampu TL 40 watt dan diamati selama 8 minggu. Selanjutnya, PLBs disubkultur ke media pembesaran berupa media 1/2MS yang ditambah ekstrak kentang dan pisang masing-masing $100 \mathrm{~g} \mathrm{~L}^{-1}$ dan arang aktif $2 \mathrm{~g} \mathrm{~L}^{-1}$. Pengkulturan di media pembesaran dilakukan selama 10 minggu kemudian diamati jumlah planlet mati, jumlah daun dan akar planlet, stomata dan jumlah kromosom dari planlet putatif poliploid.

Seleksi planlet putatif poliploid dilakukan secara visual dengan membandingkan planlet hasil perlakuan kolkisin dengan planlet kontrol (tanpa perlakuan kolkisin) berdasarkan morfologinya. Karakter yang dibandingkan diantaranya adalah ukuran planlet, daun, dan basal organ of the protocorm (BOP). Menurut Azmi et al. (2016) planlet putatif poliploid memiliki daun yang lebih tebal dan BOP yang membesar. Pengamatan juga dilakukan pada karakter jumlah kloroplas sel penjaga, kerapatan stomata dan ukuran stomata. Pengamatan kloroplas dilakukan pada 5 sampel planlet putatif poliploid. Analisis jumlah kromosom dilakukan dengan menggunakan metode squash pada kromosom yang diisolasi dari akar planlet putatif poliploid mengikuti metode Azmi et al. (2016).

\section{HASIL DAN PEMBAHASAN}

\section{Pertumbuhan dan Regenerasi PLBs pada Media Perlakuan}

Persentase hidup PLBs sebesar $100 \%$ pada 8 minggu setelah sub-kultur (MSS) ditemukan pada tiga media perlakuan yaitu $15 \%$ air kelapa (AK), 15\% AK + $0.51 \mathrm{mg}$ $\mathrm{L}^{-1} \mathrm{BAP}$, dan $15 \% \mathrm{AK}+0.50 \mathrm{mg} \mathrm{L}^{-1} \mathrm{TDZ}$. Persentase hidup PLBs terendah dihasilkan pada media $0.51 \mathrm{mg} \mathrm{L}^{-1}$ BAP sebesar $68.67 \%$ (Gambar 1). Hasil tersebut menunjukkan bahwa adanya air kelapa dan BAP atau TDZ dalam media menghasilkan persentase hidup PLBs tertinggi dibandingkan media yang hanya ditambahkan BAP atau TDZ . Air kelapa atau kombinasinya dengan BAP atau TDZ lebih sesuai untuk menunjang pertumbuhan PLBs. Air kelapa merupakan senyawa organik komplek yang mengandung asam amino, vitamin, mineral dan zat pengatur tumbuh seperti auksin dan sitokinin (Yong et al., 2009). Berbagai senyawa organik tersebut kemungkinan bersinergi dalam mendorong pertumbuhan PLBs.

Persentase PLBs yang mengalami multiplikasi tertinggi pada $8 \mathrm{MSS}$ berasal dari perlakuan $15 \% \mathrm{AK}+0.51$ mg L ${ }^{-1}$ BAP $(65.33 \%)$ namun tidak berbeda nyata dengan perlakuan $15 \% \mathrm{AK}+0.50 \mathrm{mg} \mathrm{L}^{-1} \mathrm{TDZ}$ (62.67\%) (Tabel 1). Perlakuan $15 \%$ AK menunjukkan persentase PLBs yang bermultiplikasi sebesar $44.67 \%$, sedangkan multiplikasi terendah dihasilkan oleh perlakuan $0.50 \mathrm{mg} \mathrm{L}^{-1} \mathrm{TDZ}$ sebesar $22.49 \%$, tidak berbeda nyata dengan perlakuan 0.51 $\mathrm{mg} \mathrm{L}^{-1}$ BAP sebesar $24.68 \%$. Hasil tersebut menunjukkan bahwa kombinasi 15\% AK dengan BAP maupun TDZ efektif meningkatkan persentase PLBs bermultiplikasi. Air kelapa memiliki kandungan auksin dan sitokinin (Wu dan $\mathrm{Hu}, 2009)$. Air kelapa bekerja sama dengan hormon sitokinin sintetis yang diberikan (BAP atau TDZ), sehingga lebih efektif dalam mendorong multiplikasi PLBs (Karjadi dan Buchory, 2008; Nuraini et al., 2010; Nikjenad et al., 2011). Pengaruh positif air kelapa terhadap peningkatan multiplikasi PLBs Phal. amabilis juga dilaporkan Raynalta et al. (2013).

Regenerasi PLBs menjadi planlet terlihat mulai pada minggu kedua setelah subkultur pada media perlakuan, ditunjukkan dengan tumbuhnya daun dan akar sebagai tahap awal pertumbuhan PLBs menjadi planlet. Persentase PLBs yang membentuk daun tertinggi (96\%) terdapat pada media $15 \% \mathrm{AK}$, tidak berbeda nyata dengan media $15 \%$ $\mathrm{AK}+0.51 \mathrm{mg} \mathrm{L}{ }^{-1} \mathrm{TDZ}$ sebesar 94\%. Persentase planlet berdaun terendah terdapat pada media perlakuan $0.50 \mathrm{mg}$ $\mathrm{L}^{-1}$ TDZ sebesar $82.64 \%$ dan tidak berbeda nyata dengan media perlakuan $15 \% \mathrm{AK}+0.51 \mathrm{mg} \mathrm{L}^{-1} \mathrm{BAP}(86.67 \%)$ dan $0.51 \mathrm{mg} \mathrm{L}^{-1}$ BAP (84.29\%) (Tabel 2). Hasil tersebut memperlihatkan bahwa komposisi media mempengaruhi kemampuan morfogenesis PLBs menjadi planlet. Komposisi media dengan penambahanan hormon sitokinin sintetis (BAP atau TDZ) cenderung menghambat pertumbuhan daun. Hal ini sesuai dengan pernyataan Parveen dan Shahzad (2010) bahwa sitokinin merangsang proliferasi namun menghambat pertumbuhan lebih lanjut. Menurut Chug et al. (2009), tekanan morfogenesis karena sitokinin dapat dikurangi dengan penambahan auksin. Dalam penelitian ini, morfogenesis dapat didorong dengan adanya air kelapa yang mengandung auksin, sitokinin, dan berbagai senyawa organik.

Hasil pengamatan menunjukkan bahwa persentase PLBs berakar tertinggi terdapat pada media perlakuan 15\%

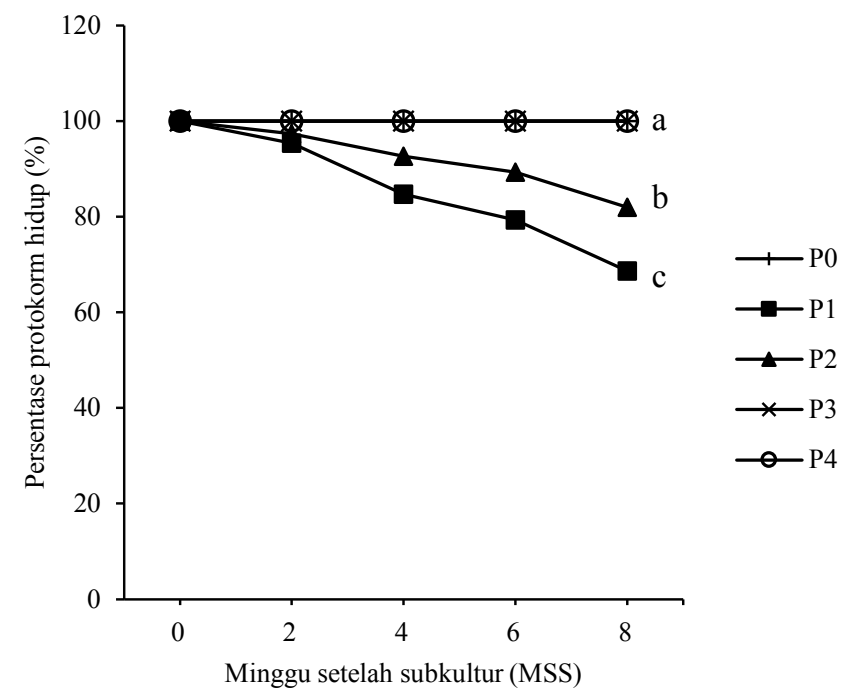

Gambar 1. Persentase protokorm hidup Phal. amabilis pada media perlakuan $15 \% \mathrm{AK}, 15 \% \mathrm{AK}+0.51 \mathrm{mg} \mathrm{L}^{-1} \mathrm{BAP}$, dan $15 \% \mathrm{AK}+0.5 \mathrm{mg} \mathrm{L}^{-1} \mathrm{TDZ}$ menghasilkan persentase hidup protokorm yang sama yaitu sebesar $100 \%$ (sehingga terlihat sebagai satu garis), media perlakuan $0.51 \mathrm{mg} \mathrm{L}^{-1}$ BAP sebesar $68.67 \%$, serta media perlakuan $0.5 \mathrm{mg} \mathrm{L}^{-1}$ TDZ sebesar 82\%. Pengamatan dilakukan pada 2-8 MSS. Huruf berbeda pada ujung garis grafik menunjukkan perbedaan nyata berdasarkan uji DMRT $\operatorname{taraf} \alpha 5 \%$ 
Putri et al. / J. Agron. Indonesia 46(3):306-313

Tabel 1. Persentase protokorm Phal. amabilis bermultiplikasi pada beberapa komposisi media perlakuan

\begin{tabular}{|c|c|c|c|c|}
\hline \multirow{2}{*}{ Perlakuan } & \multicolumn{4}{|c|}{ Persentase protokorm bermultiplikasi (\%) } \\
\hline & $2 \mathrm{MSS}$ & $4 \mathrm{MSS}$ & $6 \mathrm{MSS}$ & $8 \mathrm{MSS}$ \\
\hline $15 \% \mathrm{AK}$ & $10.00 \mathrm{c}$ & $34.67 b$ & $34.67 \mathrm{~b}$ & $44.67 b$ \\
\hline $0.51 \mathrm{mg} \mathrm{L}^{-1} \mathrm{BAP}$ & $0.00 \mathrm{~d}$ & $4.71 \mathrm{c}$ & $3.18 \mathrm{c}$ & $24.68 \mathrm{c}$ \\
\hline $0.50 \mathrm{mg} \mathrm{L}^{-1} \mathrm{TDZ}$ & $0.00 \mathrm{~d}$ & $6.43 c$ & $11.18 \mathrm{c}$ & $22.49 \mathrm{c}$ \\
\hline $15 \% \mathrm{AK}+0.51 \mathrm{mg} \mathrm{L}^{-1} \mathrm{BAP}$ & $27.33 \mathrm{a}$ & $48.00 \mathrm{a}$ & $49.33 \mathrm{a}$ & $65.33 \mathrm{a}$ \\
\hline $15 \% \mathrm{AK}+0.50 \mathrm{mg} \mathrm{L}^{-1} \mathrm{TDZ}$ & $16.67 \mathrm{~b}$ & $29.33 b$ & $48.00 \mathrm{a}$ & $62.67 \mathrm{a}$ \\
\hline KK $(\%)$ & 28.29 & 27.67 & 24.94 & 20.25 \\
\hline
\end{tabular}

Keterangan: Angka diikuti huruf yang berbeda pada kolom yang sama menunjukkan beda nyata pada uji DMRT taraf $\alpha 5 \%$. AK $=$ air kelapa, MSS = minggu setelah subkultur, $\mathrm{KK}=$ koefisien keragaman.

Tabel 2. Persentase protokorm Phal. amabilis berdaun pada beberapa komposisi media perlakuan

\begin{tabular}{|c|c|c|c|c|}
\hline \multirow{2}{*}{ Perlakuan } & \multicolumn{4}{|c|}{ Persentase protokorm berdaun $(\%)$} \\
\hline & $2 \mathrm{MSS}$ & $4 \mathrm{MSS}$ & $6 \mathrm{MSS}$ & $8 \mathrm{MSS}$ \\
\hline $15 \% \mathrm{AK}$ & $56.00 \mathrm{a}$ & $86.00 \mathrm{a}$ & $91.33 \mathrm{a}$ & $96.00 \mathrm{a}$ \\
\hline $0.51 \mathrm{mg} \mathrm{L}^{-1} \mathrm{BAP}$ & $28.82 b$ & $72.26 b$ & $77.24 b$ & $84.29 b$ \\
\hline $0.50 \mathrm{mg} \mathrm{L}^{-1} \mathrm{TDZ}$ & $21.14 b$ & $73.12 b$ & $78.95 b$ & $82.64 b$ \\
\hline $15 \% \mathrm{AK}+0.51 \mathrm{mg} \mathrm{L}^{-1} \mathrm{BAP}$ & $48.67 \mathrm{a}$ & $80.67 \mathrm{ab}$ & $85.33 \mathrm{ab}$ & $86.67 b$ \\
\hline $15 \% \mathrm{AK}+0.50 \mathrm{mg} \mathrm{L}^{-1} \mathrm{TDZ}$ & $48.67 \mathrm{a}$ & $89.33 \mathrm{a}$ & $92.67 \mathrm{a}$ & $94.00 \mathrm{a}$ \\
\hline KK $(\%)$ & 16.54 & 7.67 & 6.23 & 4.35 \\
\hline
\end{tabular}

Keterangan: Angka diikuti huruf yang berbeda pada kolom yang sama menunjukkan beda nyata pada uji DMRT taraf $\alpha 5 \%$. AK $=$ air kelapa, MSS = minggu setelah subkultur, $\mathrm{KK}=$ koefisien keragaman.

AK sebesar $96 \%$, selanjutnya pada media $15 \% \mathrm{AK}+0.51$ mg L $\mathrm{L}^{-1}$ BAP (66\%) dan tidak berbeda nyata dengan $15 \%$ $\mathrm{AK}+0.5 \mathrm{mg} \mathrm{L}^{-1} \mathrm{TDZ}(62 \%)$, sedangkan persentase PLBs membentuk akar terendah terdapat pada media perlakuan $0.50 \mathrm{mg} \mathrm{L}^{-1} \mathrm{TDZ}$, sebesar 14.43\% (Tabel 3). Hasil tersebut menunjukkan bahwa TDZ menurunkan kemampuan PLBs menghasilkan akar dan kondisi tersebut dapat diperbaiki dengan penambahan air kelapa dalam media. Hal ini sesuai dengan pernyataan Lu (1993), bahwa hormon sitokinin dapat menghambat pertumbuhan dan TDZ termasuk ke dalam kelompok sitokinin kuat yang dapat menghambat pembentukan akar.

\section{Pertumbuhan PLBs Setelah Induksi Poliploidi dengan Kolkisin}

Tabel 4 menyajikan pertumbuhan planlet Phal.amabilis asal berbagai media perlakuan terhadap pertumbuhan PLBs setelah induksi poliploidi dengan kolkisin. Pada Tabel 4 terlihat bahwa komposisi media sebelum perlakuan kolkisin tidak berpengaruh nyata terhadap jumlah daun dan akar planlet, namun mempengaruhi jumlah planlet yang mati. Planlet mati terbanyak adalah yang berasal dari perlakuan $0.5 \mathrm{mg} \mathrm{L}^{-1} \mathrm{TDZ}$ (1.83 planlet) dan $0.51 \mathrm{mg} \mathrm{L}^{-1} \mathrm{BAP}(1.75$ planlet). Planlet mati terendah adalah yang berasal dari media perlakuan $15 \% \mathrm{AK}+0.5 \mathrm{mg} \mathrm{L}^{-1} \mathrm{TDZ}$ ( 0.11 planlet $)$ dan tidak berbeda nyata dengan perlakuan $15 \% \mathrm{AK}+0.51$ mg L ${ }^{-1}$ BAP dan $15 \%$ AK sebesar 0.25 dan 0.42 planlet. Hasil tersebut menunjukkan bahwa perlakuan air kelapa dapat menekan jumlah planlet mati karena pengaruh negatif BAP dan TDZ. Hormon alami maupun nutrisi yang terdapat dalam air kelapa dapat memperbaiki pertumbuhan planlet. Hal ini sesuai dengan pernyataan Yong et al. (2009) bahwa air kelapa mengandung banyak zat penting untuk pertumbuhan, seperti gula, vitamin, mineral, asam amino, serta fitohormon yang berperan penting dalam pertumbuhan tanaman.

Skrining terhadap planlet putatif poliploid dilakukan dengan membandingkan planlet kontrol dengan planlet hasil perlakuan kolkisin secara visual, hasil skrining dipisah antara tipe planlet normal dan tipe planlet putatif poliploid. Tipe planlet normal memiliki karakteristik morfologi yang mirip dengan planlet kontrol (tanpa perlakuan kolkisin), sedangkan tipe planlet putatif poliploid memiliki daun yang lebih tebal serta memiliki basal organ pada protokorm (BOP) yang membesar (Azmi et al., 2016). Menurut Chen et al. (2009) tidak ada perbedaan lebar daun antara tanaman diploid dan tetraploid pada Phal. hieroglyphica, namun panjang daun nyata lebih pendek dan indeks luas daun lebih rendah.

Hasil skrining terhadap planlet dari perlakuan $15 \%$ AK, $0.51 \mathrm{mg} \mathrm{L}^{-1} \mathrm{BAP}, 0.50 \mathrm{mg} \mathrm{L}^{-1} \mathrm{TDZ}, 15 \% \mathrm{AK}+0.51 \mathrm{mg}$ $\mathrm{L}^{-1} \mathrm{BAP}$, dan $15 \% \mathrm{AK}+0.50 \mathrm{mg} \mathrm{L}^{-1} \mathrm{TDZ}$, menghasilkan tipe planlet putatif poliploid masing-masing sebesar 42 , 
Putri et al. / J. Agron. Indonesia 46(3):306-313

Tabel 3. Persentase protokorm Phal. amabilis berakar pada beberapa komposisi media perlakuan

\begin{tabular}{lcccc}
\hline \multirow{2}{*}{ Perlakuan } & \multicolumn{4}{c}{ Persentase protokorm berakar (\%) } \\
\cline { 2 - 5 } & $2 \mathrm{MSS}$ & $4 \mathrm{MSS}$ & $6 \mathrm{MSS}$ & $8 \mathrm{MSS}$ \\
\hline $15 \% \mathrm{AK}$ & $37.33 \mathrm{a}$ & $82.00 \mathrm{a}$ & $88.67 \mathrm{a}$ & $96.00 \mathrm{a}$ \\
$0.51 \mathrm{mg} \mathrm{L}-1 \mathrm{BAP}$ & $3.50 \mathrm{c}$ & $23.21 \mathrm{c}$ & $27.39 \mathrm{c}$ & $42.23 \mathrm{c}$ \\
$0.50 \mathrm{mg} \mathrm{L}^{-1} \mathrm{TDZ}$ & $0.00 \mathrm{c}$ & $10.79 \mathrm{~d}$ & $11.16 \mathrm{~d}$ & $14.43 \mathrm{~d}$ \\
$15 \% \mathrm{AK}+0.51 \mathrm{mg} \mathrm{L}^{-1} \mathrm{BAP}$ & $9.33 \mathrm{~b}$ & $20.67 \mathrm{~cd}$ & $36.00 \mathrm{bc}$ & $62.00 \mathrm{~b}$ \\
$15 \% \mathrm{AK}+0.50 \mathrm{mg} \mathrm{L}^{-1} \mathrm{TDZ}$ & $10.67 \mathrm{~b}$ & $36.00 \mathrm{~b}$ & $44.67 \mathrm{~b}$ & $66.00 \mathrm{~b}$ \\
\hline $\mathrm{KK}(\%)$ & 21.29 & 17.04 & 17.02 & 9.29 \\
\hline
\end{tabular}

Keterangan: Angka diikuti huruf yang berbeda pada kolom yang sama menunjukkan beda nyata pada uji DMRT taraf $\alpha 5 \%$. AK $=$ air kelapa, MSS = minggu setelah subkultur, $\mathrm{KK}=$ koefisien keragaman.

Tabel 4. Pertumbuhan planlet Phal. amabilis asal beberapa komposisi media sebelum perlakuan kolkisin pada 10 minggu setelah induksi poliploid menggunakan kolkisin

\begin{tabular}{lccc}
\hline Media asal planlet & Jumlah daun & Jumlah akar & Jumlah planlet mati \\
\hline $15 \% \mathrm{AK}$ & 3.21 & $2.58 \mathrm{ab}$ & $0.25 \mathrm{~b}$ \\
$0.51 \mathrm{mg} \mathrm{L}^{-1} \mathrm{BAP}$ & 2.88 & $2.04 \mathrm{c}$ & $1.75 \mathrm{a}$ \\
$0.50 \mathrm{mg} \mathrm{L}^{-1} \mathrm{TDZ}$ & 3.16 & $2.90 \mathrm{ab}$ & $1.83 \mathrm{a}$ \\
$15 \% \mathrm{AK}+0.51 \mathrm{mg} \mathrm{L}^{-1} \mathrm{BAP}$ & 2.84 & $2.31 \mathrm{bc}$ & $0.42 \mathrm{~b}$ \\
$15 \% \mathrm{AK}+0.50 \mathrm{mg} \mathrm{L}^{-1} \mathrm{TDZ}$ & 3.47 & $2.95 \mathrm{a}$ & $0.11 \mathrm{~b}$ \\
\hline $\mathrm{KK}(\%)$ & 19.81 & 19.23 & 65.49 \\
\hline
\end{tabular}

Keterangan: Angka diikuti huruf yang berbeda pada kolom yang sama menunjukkan beda nyata pada uji DMRT taraf $\alpha$ 5\%. AK = air kelapa, $\mathrm{KK}=$ koefisien keragaman.

42, 37, 58, dan 61\% (Gambar 2). Hasil ini menunjukkan bahwa kombinasi air kelapa dan zat pengatur tumbuh BAP atau TDZ kemungkinan dapat mendorong pembelahan sel sehingga memperbesar peluang terjadinya poliploidi. Perlakuan kolkisin pada sel yang sedang aktif membelah, makin besar kemungkinan terjadinya poliploidi.
Hasil pengamatan kloroplas pada 5 sampel planlet putatif poliploid menunjukkan $100 \%$ planlet yang diamati poliploid (Gambar 2). Menurut Syukur et al. (2013), jumlah kloroplas dalam sel penjaga pada tanaman tetraploid lebih banyak dibandingkan dengan tanaman diploidnya. Gambar 3 menyajikan keragaan ukuran dan densitas stomata planlet

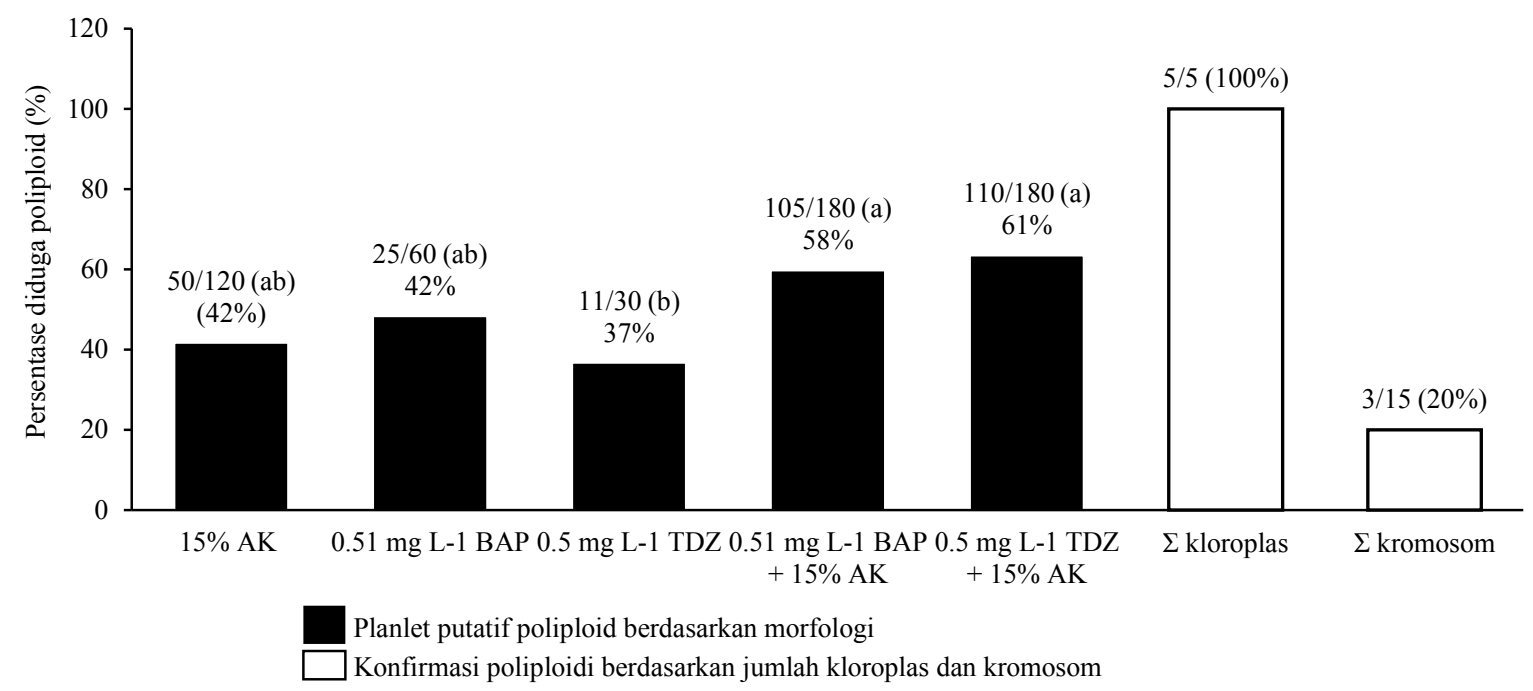

Gambar 2. Persentase planlet putatif poliploid asal berbagai media sebelum perlakuan kolkisin berdasarkan karakter morfologi Phal. amabilis pada media pembesaran dan konfirmasi poliploidi berdasarkan analisis sitologi. Huruf berbeda pada persentase planlet diduga poliploid dari masing-masing perlakuan menunjukkan perbedaan nyata berdasarkan uji DMRT taraf $\alpha 5 \%$ 
putatif poliploid dan planlet normal. Ukuran stomata planlet putatif poliploid berbeda nyata dengan planlet normal (ratarata 0.4 kali lebih besar dari planlet normal) pada uji t dengan taraf $\alpha=1 \%$. Densitas stomata pada planlet putatif poliploid nyata lebih rendah (setengah dari densitas stomata dari planlet normal), pada uji t dengan $\alpha=1 \%$. Hasil yang sama dilaporkan oleh Miguel dan Leonhardt (2011), Kerdsuwan dan Te-chato (2012), Rahayu et al. (2015) dan Azmi (2016), bahwa planlet poliploid (tetraploid) memiliki ukuran yang lebih besar, namun dengan densitas stomata lebih kecil daripada planlet diploid.
Hasil pengamatan jumlah kromosom dari 15 planlet putatif poliploid dari berbagai perlakuan menunjukkan kesulitan dalam mengamati jumlah kromosom. Jumlah kromosom mengganda hanya ditemukan pada planlet dari perlakuan $15 \% \mathrm{AK}+0.50 \mathrm{mg} \mathrm{L}^{-1} \mathrm{TDZ}$ sebesar 3\% sedangkan pada planlet dari perlakuan lainnya tidak dapat dideteksi. Keragaan kromosom pada planlet seperti terlihat pada Gambar 3. Kesulitan dalam mengamati jumlah kromosom dapat disebabkan ketidaksesuaian waktu pengambilan sampel dengan fase metafase sel.

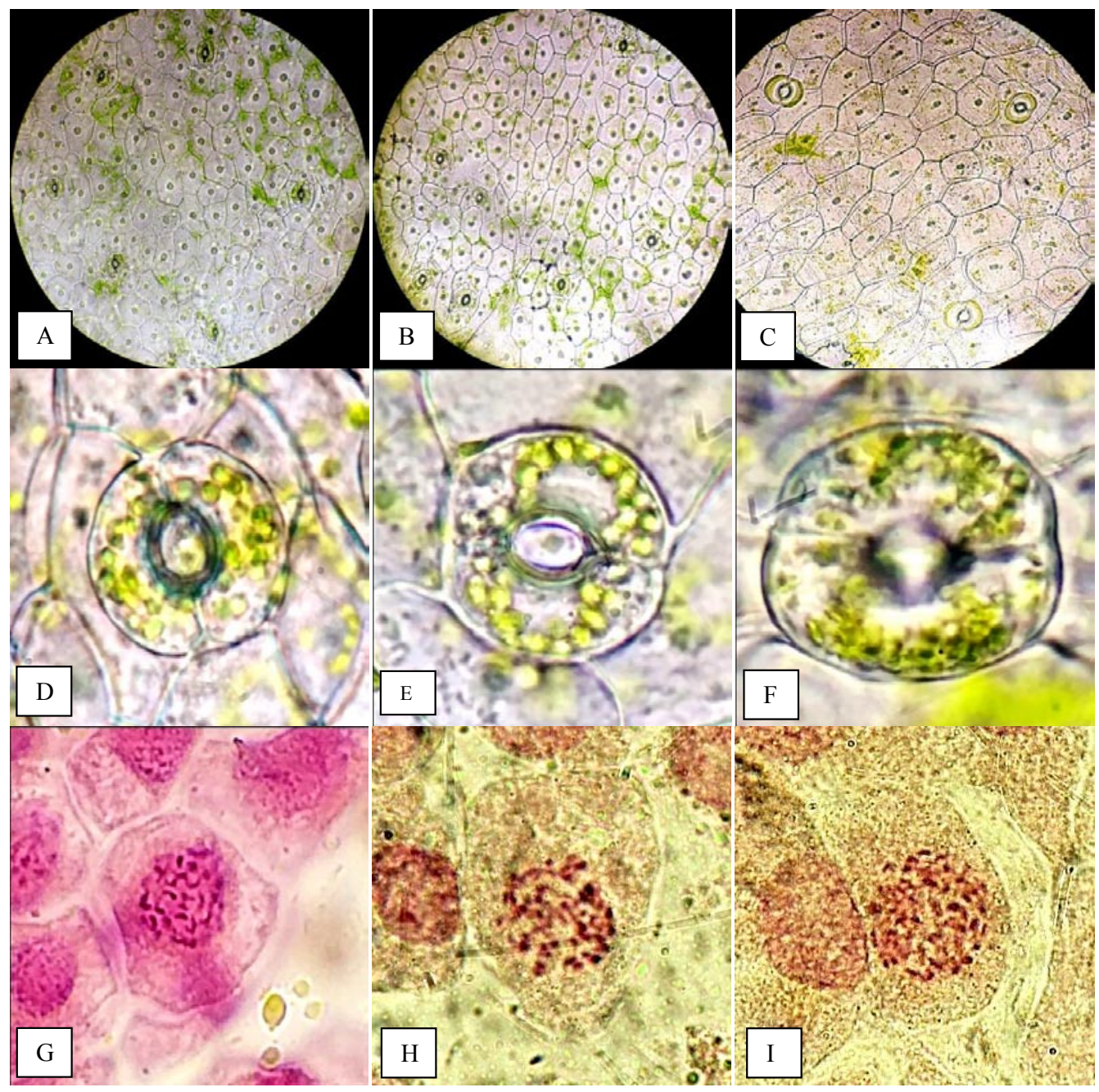

Gambar 3. Perbandingan densitas stomata dari planlet normal dari kontrol (A), planlet tipe normal dari hasil perlakuan kolkisin (B) dan tipe diduga poliploid (putatif poliploid) dari hasil perlakuan kolkisin(C); kloroplas di dalam stomata dari planlet normal dari kontrol (D), planlet tipe normal dari hasil perlakuan kolkisin (E) dan tipe diduga piloploid (putatif poliploid) dari perlakuan kolkisin (F); serta kromosom pada fase metafase dari planlet kontrol (G), planlet tipe normal dari hasil perlakuan kolkisin (H), dan tipe diduga piloploid (putatif poliploid) dari hasil perlakuan kolkisin (I). Pengamatan dengan mikroskop OPTIKA M-699 dengan perbesaran $400 \mathrm{X}$

\section{KESIMPULAN}

Kombinasi air kelapa (15\%) dengan BAP $\left(0.51 \mathrm{mg} \mathrm{L}^{-1}\right)$ atau TDZ $\left(0.50 \mathrm{mg} \mathrm{L}^{-1}\right)$ menghasilkan persentase PLBs hidup tertinggi $(100 \%)$ dan multiplikasi protokorm. Persentase
PLBs bermultiplikasi tertinggi dihasilkan dari perlakuan $15 \%$ air kelapa $+0.5 \mathrm{mg} \mathrm{L}^{-1} \mathrm{BAP}(65.3 \%)$ atau $0.51 \mathrm{mg} \mathrm{L}^{-1}$ TDZ (62.7\%). Morfogenesis protokorm membentuk daun dan akar paling baik pada media dengan penambahan 15\% air kelapa tanpa BAP atau TDZ. Hasil analisis kromosom 
menunjukkan persentase planlet poliploid sebesar 3\% ditemukan pada planlet dari perlakuan media $15 \% \mathrm{AK}+$ $0.50 \mathrm{mg} \mathrm{L}^{-1} \mathrm{TDZ}$ sedangkan pada planlet dari perlakuan lainnya tidak dapat dideteksi.

\section{DAFTAR PUSTAKA}

Arditti, J. 2008. Micropropagation of Orchids. Volume 1. Blackwell Pub, Malden, US.

Atichart, P. 2013. Polyploid induction by colchicine treatments and plant regeneration of Dendrobium chrysotoxum. Thai. J. Agric. Sci. 46:59-63.

Azmi, T.K.K., D. Sukma, S.A. Aziz, M. Syukur. 2016. Morfologi dan pertumbuhan planlet hasil induksi poliploidi melalui perlakuan kolkisin pada kuncup bunga anggrek bulan (Phalaenopsis amabilis (L.) Blume). J. Agron. Indonesia 44:68-75.

Chen, J.T., W.C. Chang. 2004. Induction of repetitive embryogenesis from seed-derived protocorms of Phalaenopsis amabilis var. formosa shimadzu. in vitro cell. Dev. Biol. Plant. 40:290-293.

Chen, W.H., C.Y. Tang, C.Y., Y.L. Kao. 2009. Ploidy doubling by in vitro excised protocorm or protocormlike bodies in Phalaenopsis species. Plant Cell Tiss. Org. Cult. 98:229-238.

Chen, W.H., Y.L. Kao, C.Y. Tang, G.T. Jean. 2011. Endopolyploidy in Phalaenopsis orchids and its application in polyploid breeding. In W.H.Chen, H.H. Chen. Orchid Biotechnology II. World Scientific.

Chuang, H.T., S.T. Hsu, T.M. Shen. 2008. Breeding barriers in yellow Phalaenopsis orchids. J. Taiwan. Soc. Hort. Sci. 54:59-66.

Chuang, H.T., K.L. Huang, R.S. Shen, I. Miyajima, S.T. Hsu. 2014. Using Cut-Column Pollination Method to Overcome Crossing Barriers in Phalaenopsis Sunrise Goldmour 'KHM637'. J. Fac. Agr., Kyushu Univ. 59:265-271.

Chugh, S., S. Guha, I.U. Rao. 2009. Micropropagation of orchids: A review on the potential of different explants. Sci. Hort. 122:507-520.

Del Pozo, J.C., E. Ramirez-Parra. 2015. Whole genome duplications in plants: An overview from Arabidopsis. J. Exp. Bot. 66:6991-7003.

Hopkins, W.G. 1999. Introduction to Plant Physiology $2^{\text {nd }}$ ed. John Willey \& Sons Inc, USA, US.
Karjadi, A.K., A. Buchory. 2008. Pengaruh auksin dan sitokinin terhadap pertumbuhan dan perkembangan jaringan meristem kentang kultivar Granola. J. Hort. 18:380-384.

Kerdsuwan, N., S. Te-chato. 2012. Effects of colchicine on survival rate, morphological, physiological and cytological characters of chang daeng orchid (Rhynchostylis gigantea var. rubrum Sagarik) in vitro. J. Agric. Tech. 8:1451-1460.

Khosravi, A.R., M.A. Kadir, S.B. Kadzemin, F.Q. Zaman, A.E. De Silva. 2009. RAPD analysis of colchicine induced variation of the Dendrobium Serdang Beauty. Afr. J. Biotech. 8:1455-1465.

Lu, C. 1993. The use of thidiazuron in tissue culture. In Vitro Cell Dev. Biol. 29:92-96.

Miguel, T.P., K.W. Leonhardt. 2011. In vitro polyploidy induction of orchids using oryzalin. Sci. Hort. 130:314-319.

Niknejad, A., M.A. Kadir, S.B. Kadzimin. 2011. In vitro plant regeneration from protocorms like bodies (PLBs) and callus of Phalaenopsis gigantean (Epidendroideae: Orchidaceae). Afr. J. Biotech. 10:11808-11816.

Nuraini, A., W.R. Herliya, E. Marliana. 2010. Responses of protocorm like bodies hybrid Dendrobium orchid on various types and concentration of cytokinin and auxin on Murashige and skoog (MS) medium. hal. 130-135. International Seminar on Horticulture to Support Food Security. Bandar Lampung 22-23 June 2010.

Parveen, S., A. Shahzad. 2010. TDZ-induced high frequency shoot regeneration in Cassia sophera Linn. via cotyledonary node explants. Physiol. Mol. Biol. Plants. 16:201-206.

Rahayu, Y.S., I.K. Prasetyo, A.U. Riyada. 2014. Pengaruh penggunaan kolkisin terhadap pertumbuhan vegetatif tanaman sedap malam (Polianthes tuberose L.) di dataran medium. J. Agromix 5:44-56.

Rahayu, E.M.D., D. Sukma, M. Syukur, Irawati. 2015. Induksi poliploidi Phalaenopsis amabilis (L.) Blume dan Phalaenopsis amboinensis J.J Smith menggunakan kolkisin secara in vitro dan in vivo. J. Agron. Indonesia 43:219-226.

Raynalta, E. 2013. Pengaruh komposisi media dalam pertumbuhan protocorm like bodies, planlet, dan aklimatisasi Phalaenopsis amabilis. J. Hort. Indonesia 4:131-139. 
Sarathum, S., M. Hegele, S. Tantiviwat, M. Nanakorn. 2010. Effect of concentration and duration of colchicine treatment on polyploidy induction in Dendrobium scabrilingue L. Europ J. Hort. Sci. 75:123-127.

Sattler, M.C., C.R. Carvalho, W.R. Clarindo. 2016. The Polyploidy and its keyrole in plant breeding. Planta 243:281-296.

Syukur, M., S. Sastrosumarjo, Y. Wahyu, S.I. Aisyah, S. Sujiprihati, R. Yunianti. 2013. Sitogenetika Tanaman. Edisi Kedua. IPB Press, Bogor, ID.
Wu, Y., B. Hu. 2009. Simultaneous determination of several phytohormones in natural coconut juice by hollow fiber-based liquid-liquid-liquid microextraction-high performance liquid chromatography. J. Chromatogr. 1216:7657-7663.

Yong, J.W.H., L. Ge, Y.F. Ng, S.N. Tan. 2009. The Chemical composition and biological properties of coconut (Cocos nucifera L.) water. Molecules 14:5144-5164. 